\title{
ANALISIS GERAK JATUH BEBAS DENGAN METODE VIDEO BASED LABORATORY (VBL) MENGGUNAKAN SOFTWARE TRACKER
}

\author{
Agung Ristiawan ${ }^{1}$ \\ ${ }^{1}$ SMKN 1 Sukoharjo, jl. Raya Sukoharjo, Wonosobo, Jawa Tengah \\ Email: reesttea@yahoo.com
}

\begin{abstract}
ABSTRAK
Tujuan dari penelitian ini adalah untuk mengetahui besar percepatan gravitasi pada gerak jatuh bebas yang dianalisis dengan Tracker dan mengetahui besarnya percepatan benda jatuh bebas bergantung pada besar gaya yang mempengaruhi benda dengan memvariasi jarak benda tersebut dijatuhkan. Pengambilan data dalam penelitian ini dengan melalui eksperimen di Catur Tunggal, Yogyakarta. Subyek penelitian ini yaitu besar percepatan pada gerak benda jatuh bebas. Pada gerak jatuh bebas dilakukan variasi ketinggian jatuhnya benda sebesar 40, 50, 60, 70, 80, 90, dan $100 \mathrm{~cm}$ untuk massa benda yang sama yakni 353 gram. Data yang diperlukan yaitu posisi beban pada gerak jatuh bebas melalui analisis Tracker yang dilakukan terhadap video hasil rekaman. Untuk mengetahui besar pecepatan dan besar gaya gesek yang bekerja pada gerak jatuh bebas dilakukan analisis dengan menggunakan persamaan yang sudah ditentukan. Waktu efektif dalam penelitian ini adalah dua bulan. Berdasarkan analisis Tracker akan diperoleh grafik kelajuan terhadap waktu yang linier, dari grafik tersebut diperoleh besar percepatan benda jatuh bebas dengan persamaan yang didapat dalam grafik linier yaitu $Y=m t+b$, dengan $m$ adalah gradien grafik liner yang menunjukkan besar percepatan yang diperoleh dari dianalisis dengan Tracker sama dengan percepatan gravitasi secara teori dan untuk gerak jatuh bebas benda diperoleh percepatan rata-rata sebesar $(9,63 \pm 0,33) \mathrm{m} / \mathrm{s}^{2}$.
\end{abstract}

Kata kunci: video, laboratorium, tracker, gerak jatuh bebas.

\begin{abstract}
The purpose of this study is to determine the magnitude of the gravitational acceleration in free fall motion analyzed by the Tracker and determine the magnitude of the acceleration of free-falling objects depending on the magnitude of the force affecting the object by varying the distance the object is dropped. Retrieval of data in this study through experiments in Catur Tunggal, Yogyakarta. The subject of this research is the large acceleration of free-falling body motion. In the free fall motion variations in the height of falling objects by 40,50,60,70, 80, 90, and $100 \mathrm{~cm}$ for the same mass of objects that is 353 grams. The data needed is the position of the load on the free fall through Tracker analysis conducted on the recorded video. To find out the magnitude of the velocity and the magnitude of the frictional force acting on free fall motion an analysis is performed using a predetermined equation. The effective time in this study is two months. Based on the Tracker analysis, a velocity graph of linear time is obtained, from the graph the acceleration of free falling objects obtained by the equation obtained in the linear graph is $Y=m t+b$, where $m$ is the gradient of the linear graph showing the acceleration obtained by analyzing Tracker is the same as gravitational acceleration in theory and for free fall motion of objects obtained an average acceleration of $(9,63 \pm 0,33) \mathrm{m} / \mathrm{s}^{2}$.
\end{abstract}

Keywords: video, laboratory, tracker, pixel, software.

DOI: http://dx.doi.org/10.15575/jtlp.v3i2.6556

Received: 3 Maret 2018; Accepted: 30 Agustus 2018; Published: 1 September 2018 


\section{PENDAHULUAN}

Banyak gejala fisika yang sukar diamati dan dieksperimenkan, terutama dalam hal pengukuran yang terbatasi oleh kemampuan mata manusia (Young \& Freedmann, 2008). Termasuk di dalamnya adalah fenomena gerak linier pada gerak jatuh bebas (Zollman \& Fuller, 1994).

Suatu benda dikatakan mengalami gerak jatuh bebas, jika benda tersebut dilepaskan dari suatu ketinggian tertentu terhadap tanah tanpa kecepatan awal. Benda yang dijatuhkan dari atas akan jatuh ke bumi karena benda tersebut mendapat percepatan gravitasi $(g)$ yang arahnya selalu menuju ke pusat bumi (Supriyadi, 2008).

Di dalam gerak jatuh bebas, gesekan dan gaya archimedes terhadap udara diabaikan sehingga dapat dikatakan bahwa gerak jatuh bebas sebenarnya hanya terjadi dalam ruang hampa. Jika suatu benda dijatuhkan dari suatu ketinggian dari permukaan tanah dengan percepatan gravitasi, maka untuk mengetahui kecepatan benda pada saat jatuh bebas dapat digunakan persamaan $v_{t}=g t$ (Zollman \& Fuller, 1994).

Sedangkan persamaan yang digunakan untuk menentukan jarak yang ditempuh oleh suatu benda selama benda bergerak selama t detik dari tempat awal dapat digunakan persamaan $y=\frac{1}{2} g t^{2}$.

Dalam setiap kesempatan, gerak jatuh dipelajari oleh para ilmuwan dengan hati-hati dan teliti. Dalam keadaan hambatan hampa udara didapatkan bahwa semua benda, tidak peduli ukuran dan beratnya, pada setiap titik dipermukaan bumi jatuh dengan percepatan yang sama. Bila jarak yang ditempuh adalah kecil bila dibandingkan dengan jejari bumi, percepatan selama jatuh adalah tetap. Pengaruh dari hambatan udara dan berkurangnya percepatan dengan ketinggian akan diabaikan. Gerak yang ideal ini disebut "jatuh bebas".

Analisis gerak jatuh bebas dapat dilakukan dengan lebih mudah dengan metode Video Based
Laboratory (VBL). Video Based Laboratory merupakan metode analisis yang menggunakan komputer sebagai media, termasuk menampilkan data eksperimen dalam bentuk tabel dan grafik (Beichner \& Abbot, 1999). Dengan menggunakan VBL memungkinkan untuk mengamati gerakan yang terjadi sangat cepat yang tidak dapat diamati dengan mata manusia (Bryan, 2004).

Beberapa penelitian dengan media berbasis VBL dengan software Logger Pro telah banyak dilakukan (Zollman \& Brungardt, 1995; Bastian, 2007; McKay, 2006). Selain menggunakan Logger Pro, VBL juga dapat dilakukan dengan software lain seperti Tracker. Tracker adalah software gratis yang dapat pula dipakai sebagai media VBL seperti halnya Logger Pro, sehingga Tracker dapat pula dipakai sebagai software untuk menganalisis gerak jatuh bebas dengan metode VBL (Brown, 2007).

Berdasarkan hal tersebut maka perumusan masalah yang akan dikaji adalah: (1) apakah besar percepatan gravitasi pada gerak jatuh bebas yang dianalisis dengan Tracker sama dengan percepatan gravitasi secara teori? dan (2) berapa besar percepatan benda jatuh disertai besar gaya gesek yang mempengaruhi benda jatuh bebas dengan variasi jarak benda dijatuhkan?

\section{METODE PENELITIAN}

Penelitian ini menggunakan metode eksperimen, dengan variabel penelitian terdiri atas:

a. Variabel tetap dalam penelitian ini adalah massa benda pada gerak jatuh bebas.

b. Variabel manipulasi dalam penelitian ini adalah ketinggian benda dijatuhkan pada gerak jatuh bebas.

c. Variabel respon adalah percepatan benda dan gaya gesek pada gerak jatuh bebas.

Kemudian populasi dari penelitian gerak jatuh bebas adalah jarak atau ketinggian benda dijatuhkan, sedangkan sampel yang diambil adalah 7 variasi ketinggian yakni 40, 50, 60, 70, 80, 90, dan $100 \mathrm{~cm}$. 
Alat dan bahan yang digunakan dalam penelitian yaitu: Handycam/Kamera, kamera, benda, computer, dan software tracker dengan design ditunjukkan pada Gambar 1.
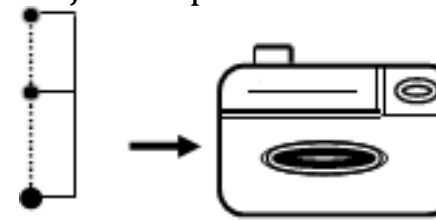

(1) Benda
(2) Kamera digital (3) Komputer

Gambar 1. Desain percobaan

Keterangan:

(1) Benda

Benda yang dimaksud yakni bola dan beban yang akan digunakan sebagai subjek dalam penelitian. Bola yang dipakai untuk gerak jatuh bebas adalah sebuah bola pejal dengan massa 353 gram.

(2) Kamera Digital

Kamera digital berfungsi sebagai perekam (recorder) untuk menghasilkan video. Kamera yang dipakai adalah jenis handycam Sony model

DCR-HC38E dengan resolusi video 720x576 pixel, 25 frame persecond, zooming 40x.

(3) Software Tracker

penelitian ini sofware yang digunakan adalah Tracker. Selain dapat menampilkan gambar yang telah direkam, juga menampilkan data eksperimen berupa posisi sebagai fungsi waktu $(t)$, sebagaimana ditunjukkan pada Gambar 2.

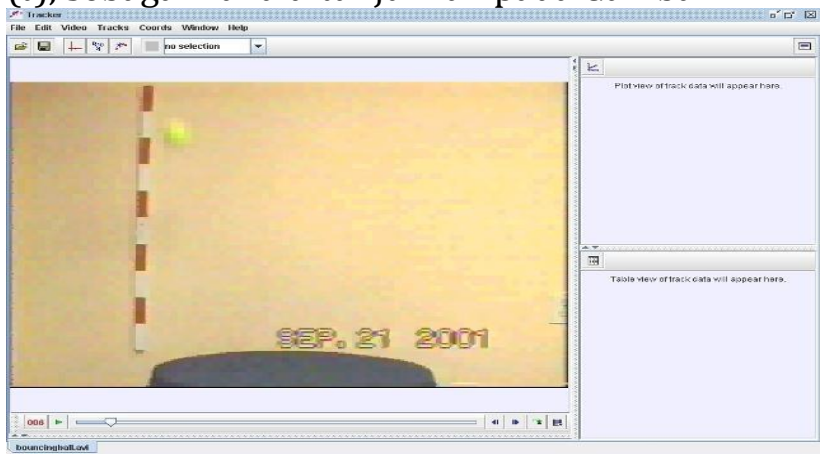

Gambar 2. Analisi software Tracker

Metode pengumpulan data yang digunakan adalah metode observasi atau pengamatan yaitu dengan langkah-langkah sebagai berikut:

a. Berbagai peristiwa yang ada dalam desain penelitian direkam dengan menggunakan kamera digital (handycam). b. Rekaman peristiwa tersebut ditransfer kedalam komputer dalam bentuk file video.

c. Masing-masing file video dianalisis menggunakan Tracker, untuk mendapatkan data posisi benda dalam setiap selang waktu.

d. Data dari Tracker diambil untuk dianalisis lebih lanjut.

Selanjutnya data yang diperoleh dari Tracker di transfer ke dalam Microsoft Office Excel untuk dilakukan analisis data secara matematis dengan menggunakan persamaan gerak benda. Microsoft Office Excel juga dipakai sebagai media bantu dalam menggambar grafik gerak benda. Kemudian dengan menggunakan persamaan gaya gesek, diperoleh besar gaya gesek diudara sebesar $F_{\text {gesek }}=m(g-a)$ (Young \& Freedmann, 2008).

\section{HASIL DAN PEMBAHASAN}

Penelitian ini bertujuan untuk mengetahui besar percepatan benda jatuh bebas dan mengetahui besar gaya yang bekerja pada benda tersebut. Pada penelitian ini, dilakukan delapan variasi ketinggian benda, yaitu dengan jarak 0,4-1,0 meter. Penelitian ini menggunakan benda jatuh yang sama, dengan massa beban sebesar 353 gram, dengan ilustrasi seperti ditunjukkan pada Gambar 3.

Dengan menggunakan alat seperti yang tergambar dalam Gambar 1, didapatkan data pengamatan berupa rekaman video eksperimen. Tracker menganalisis video berdasarkan pixel and frame refference, sehingga mampu menyajikan data posisi benda $(y)$ setiap selang waktu $(t)$. Data tersebut kemudian dianalisis dengan persamaan gerak jatuh bebas untuk mendapatkan nilai percepatan dan gaya yang bekerja. Analisis data dilakukan dengan menggunakan bantuan Microsoft Office Excel, untuk melakukan operasioperasi hitung dan penggambaran grafik. 


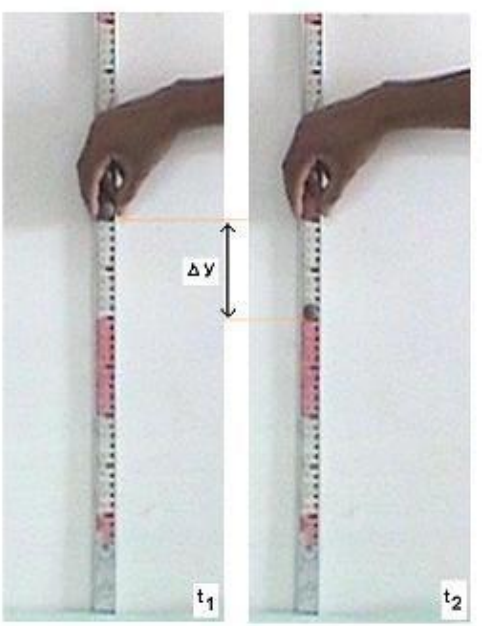

Gambar 3. Ilustrasi gerak jatuh bebas pada selang waktu $(\Delta t)$ dan perubahan posisi $(\Delta y)$

Untuk setiap variasi ketinggian benda dijatuhkan (h), hasil analisis data eksperimen yang diperoleh adalah sebagai berikut:

a. Pada $\mathrm{h}=0,4 \mathrm{~m}$

Besar percepatan jatuh berdasarkan analisis grafik adalah $(9,65 \pm 0,44) \mathrm{m} / \mathrm{s}^{2}$. Kemudian dengan menggunakan persamaan gaya gesek, diperoleh gaya gesek diudara sebesar $0,05 \mathrm{~N}$.

b. Pada $\mathrm{h}=0,5 \mathrm{~m}$

Besar percepatan jatuh berdasarkan analisis grafik adalah $(9,49 \pm 0,29) \mathrm{m} / \mathrm{s}^{2}$. Kemudian dengan menggunakan persamaan gaya gesek, diperoleh gaya gesek diudara sebesar 0,11 N.

\section{c. Pada $\mathrm{h}=0,6 \mathrm{~m}$}

Besar percepatan jatuh berdasarkan analisis grafik adalah $(9,48 \pm 0,43) \mathrm{m} / \mathrm{s}^{2}$. Kemudian dengan menggunakan persamaan gaya gesek, diperoleh gaya gesek diudara sebesar $0,11 \mathrm{~N}$.

d. Pada $\mathrm{h}=0,7 \mathrm{~m}$

Besar percepatan jatuh berdasarkan analisis grafik adalah $(9,63 \pm 0,42) \mathrm{m} / \mathrm{s}^{2}$. Kemudian dengan menggunakan persamaan gaya gesek, diperoleh gaya gesek diudara sebesar 0,6 N.

e. Pada $\mathrm{h}=0,8 \mathrm{~m}$

Besar percepatan jatuh berdasarkan analisis grafik adalah $(9,60 \pm 0,19) \mathrm{m} / \mathrm{s}^{2}$. Kemudian dengan menggunakan persamaan gaya gesek, diperoleh gaya gesek diudara sebesar 0,7 N.

f. Pada h $=0,9 \mathrm{~m}$

Besar percepatan jatuh berdasarkan analisis grafik adalah $(9,74 \pm 0,29) \mathrm{m} / \mathrm{s}^{2}$. Kemudian dengan menggunakan persamaan gaya gesek, diperoleh gaya gesek diudara sebesar $0,2 \mathrm{~N}$.

g. Pada $\mathrm{h}=1 \mathrm{~m}$

Besar percepatan jatuh berdasarkan analisis grafik adalah $(9,76 \pm 0,20) \mathrm{m} / \mathrm{s}^{2}$. Kemudian dengan menggunakan persamaan gaya gesek, diperoleh gaya gesek diudara sebesar $0,1 \mathrm{~N}$.

Dengan menggunakan nilai rata-rata hitung, diperoleh nilai rata-rata percepatan benda jatuh sebesar $(9,63 \pm 0,33) \mathrm{m} / \mathrm{s}^{2}$. Hasil tersebut sudah mendekati dengan nilai tetapan gravitasi di bumi $(g)$, walaupun tidak sama persis $9,8 \mathrm{~m} / \mathrm{s}^{2}$ disebabkan oleh faktor gaya gesek udara karena eksperimen tidak dilakukan pada ruang hampa (Young \& Freedmann, 2008).

\section{KESIMPULAN}

Berdasarkan hasil penelitian dan pembahasan, dapat disimpulkan bahwa:

1. Besar percepatan pada gerak jatuh bebas yang dianalisis dengan Tracker sama dengan percepatan gravitasi secara teori.

2. Besar percepatan benda jatuh bebas dengan variasi ketinggian benda dijatuhkan dan besar gaya yang mempengaruhi besar percepatan rata-rata yang diperoleh adalah $(9,63 \pm 0,33) \mathrm{m} / \mathrm{s}^{2}$.

\section{DAFTAR PUSTAKA}

Bastian, Norma. 2007. Analisis Gerak Jatuh Bebas dan Besar Gaya Menggunakan Video Based Laboratory (VBL). Yogyakarta: FMIPA UNY

Beichner, Robert.J. and Abbot, David.S. 1999. Video-Based Labs for Introductory Physics Courses: Analyzing and Graphing Motion on Video. Journal of Collage Science Teaching (JCST) 29 (2), 101-104 
Brown, Douglas. 2007. Combining Computational Physics with Video Analysis in Tracker. Physic Department, Cabrillo Collage, Aptos CA 95003

Bryan, Joel. 2004. "Video Analysis Software and Investigation of the Conservation Mechanical Energy ". Contemporary Issues in Technology and Teacher Education (Online serial), 4(3). Texas A\&M University. http://www.citejournal.org/vol4/iss3/sc ience/article1.cfm

McKay, Bruce. 2006. Video-Based Motion Analysis. Saint Ignatius Collage

Supriyadi. 2008. Membedah Sains dalam Proses Sains. Yogyakarta: Jurdik IPA FMIPA UNY

Young, Hugh.D. and Freedmann, Roger.A. 2008. Sears and Zemansky's University Physics with Modern Physics. San Fransisco: Pearson AddisonWesley

Zollman, Dean.A. and Brungardt, John. 1995. The Influence of Interactive Videodisc Instruction Using Simultaneous-Time Analysis on Kinematics Graphing Skills of High School Physics Students. Journal of Research in Science Teaching 32(8) 855869

Zollman, Dean. A. and Fuller, Robert.G. 1994. Research Paper in Physics and Astronomy: "Teaching and Learning Physics with Interactive Video". Robert G. Fuller Publications, University of Nebrasca, Lincoln 